\title{
Behavior Change Theories: a New Medical Education Paradigm?
}

\section{Teorias de Mudança de Comportamento: um Novo Paradigma da Educação Médica?}

Leonardo Essado Rios ${ }^{I}(\mathbb{D}$

\section{KEYWORDS}

- Behavior.

- Psychological Theory.

- Medical Education.

A critical perspective on the importance of evidence-based behavior change theories for medical education is presented. Numerous theoretical models have been proposed to explain behavior changes, with two theories currently emerging as a new paradigm, namely the Behaviour Change Wheel (BCW) and the Prime Theory of Motivation. Behind this is the fact that these theories were proposed based on comprehensive literature review about explanatory models of behavioral changes, in addition to consensus among experts. The basic principle is that any change in behavior necessarily involves three interrelated aspects: capability, opportunity, and motivation. In the present essay, these theories were addressed with a view to problems involving behaviors in medical education, and emphasis on the problem of obsolete teaching practices in the training of health professionals. Assuming that good teachers have a global view of the teaching profession, and not merely of their specialty, interventions to change outdated teaching performances among health educators should start by understanding their motivation to change. It is also necessary to investigate their knowledge and skills about innovative teaching-learning methods (capability), as well as whether the environment supports methodological diversification and innovation (opportunity). In summary, evidence-based behavior change theories may represent a new paradigm for medical education when the goal involves overcoming behavioral problems. 


\section{RESUMO}

\section{PALAVRAS-CHAVE}

- Comportamento.

- Teoria Psicológica.

- Educação Médica.

Apresenta-se uma perspectiva crítica sobre a importância das teorias de mudança de comportamento baseadas em evidência para a educação médica. Inúmeros modelos teóricos têm sido propostos para explicar mudanças de comportamento, com duas teorias atualmente emergindo como um novo paradigma, nomeadamente a Behaviour Change Wheel $(B C W)$ e a Prime Theory of Motivation. Por trás disso, está o fato de que essas teorias foram propostas com base em uma revisão abrangente da literatura sobre modelos explicativos de mudanças comportamentais, além de consenso entre especialistas. O princípio básico é que qualquer mudança de comportamento envolve necessariamente três aspectos inter-relacionados: capacidade, oportunidade e motivação. No presente ensaio, essas teorias foram abordadas com vistas a problemas que envolvem comportamentos na educação médica, com ênfase na questão das práticas obsoletas de ensino na formação de profissionais de saúde. Assumindo que bons professores têm uma visão global da profissão de professor, e não apenas de sua especialidade, intervenções para melhorar performances ultrapassadas de ensino entre educadores em saúde devem primeiramente entender a motivação deles para mudar. Também é necessário investigar os conhecimentos $e$ as habilidades deles sobre métodos inovadores de ensino-aprendizagem (capacidade), bem como se o ambiente apoia a diversificação metodológica e a inovação (oportunidade). Em suma, as teorias de mudança de comportamento baseadas em evidências podem representar um novo paradigma para a educação médica quando o objetivo envolve superar problemas comportamentais.

Received on $7 / 18 / 20$

Accepted on $9 / 13 / 20$

Several problems in the field of medical education require behavioral changes, including diversification of the teaching-assessment methods, development and formation of the teacher identity, and improvement of teacher-student relationships ${ }^{1-3}$. To be a good teacher in the health field, it is undoubtedly necessary to understand the subject-matter under the taught discipline very well, but this is not enough, because didacticpedagogical skills are also essential for good teaching practice ${ }^{1,2}$. That is, good teachers have a global view of the teaching profession, and not merely of their specialty.

The education of health professionals encompasses ingrained behaviors, such as the difficulty of teachers in changing their teaching practices, often influenced by the Flexnerian model of health, so that many educators persist in teaching, while remaining resistant to new methodologies ${ }^{2}$. In this sense, evidence-based behavior change theories (BCTs) may represent a new concept in the field of medical education when the problem involves changing behaviors ${ }^{3,4}$.

Numerous BCTs were identified in a previous systematic review of the literature ${ }^{5}$, and the most frequently found ones in the studies was the transtheoretical model. ${ }^{6}$ This model was widely used in curricular interventions to improve the behavior of medical students in relation to counselling patients on healthy behaviors. ${ }^{7}$. Another BCT, the theory of planned behavior ${ }^{8}$, is also pervasive in medical literature and its integration into professional training in medical education has been proposed ${ }^{9}$.

Currently, two influential evidence-based theories have emerged as new paradigm when it comes to changing behaviors, namely, the Behavior Change Wheel $(\mathrm{BCW})^{5}$, and the Prime Theory of Motivation ${ }^{10}$. The core principle of these BCTs, which were developed based on systematic and comprehensive literature reviews and consensus among experts ${ }^{5}$, is that behavior change consists of three inter-related components known as the COM-B system, with the initials meaning "capability, opportunity, motivation - behavior".

In addition to assisting the intervention design, the models aim to improve the process, evaluation, and theoretical development ${ }^{5}$. The first step is understanding the problem, that is, the target behavior:

(i) Defining the problem to be addressed in behavioral terms.

(ii) Selecting the target behavior that will most likely result in changes to solve the problem.

(iii) Specifying the target behavior with as many details as possible.

(iv) Identifying what needs to be changed using the COM-B model ${ }^{5}$.

Given that the problem related to obsolete teaching practices involves several factors, such as lack of teaching professionalization, devaluation of teacher training, teacher resistance to changes and the individualism of the teaching practice ${ }^{1,2}$, the intervention may require changes in one or more of these factors. The target behaviors may overlap the development of the teacher identity, the valuation of teaching skills training, the awareness of changes needed in medical teaching, and the integration of solidarity into the teaching practice ${ }^{4}$.

An example of problem definition in behavioral terms is:

(i) What behavior? Resistance to teaching using innovative didactic-pedagogical methodologies.

(ii) Where does the behavior occur? Schools where health professionals are trained.

(iii) Who is involved in performing the behavior? Teachers.

Following the specification of the problem and target-behavior, it is time to think about the intervention functions and identification of public policy categories. Examples of the intervention functions in the field of medical education include the implementation of national curricular guidelines for health courses (a restriction function), additional remuneration subject to the teacher's exclusive dedication to the educational institution (an incentivization function), and dissemination of outstanding teaching practices (a modelling function) ${ }^{4}$. The identification of intervention functions and types of public policies requires the constant 
use of judgments about what is the most appropriate for each context ${ }^{5}$.

To identify the options for the content and practice of an intervention, it is necessary to establish the techniques and the mode of implementation. A behavior change technique is defined as the active component of an intervention and can be used alone or combined with other techniques ${ }^{5}$. For example, to develop the habit of recommending to their students the importance of reading activities, teachers are instructed to associate this with the act of using an attendance sheet at the end of the class (a habit formation technique ${ }^{5}$, defined as the rehearsal and repetition of the behavior in the same context again and again, so that the context induces the habit) ${ }^{4}$.

One of the dimensions of the COM-B system is the motivation to change behavior. To intervene in a teacher's motivation to teach using innovative methods, it is essential to understand the key aspects related to their motivation. According to the Prime theory of motivation ${ }^{10}$, motivation to change involves an internal (mental) and an external environment (stimuli, information). Prime is an acronym of 'plans, responses, impulses, motives, and evaluations', which may be considered as the main constructs of this theory. It is postulated that, at every moment of their lives, people act in search of what they most want and/or need ${ }^{10}$.

Guided by the BCW and Prime models, interventions to change outdated teaching performances among health educators require the understanding of their motivation to change: (i) their desire to teach using new and diversified teaching methodologies; (ii) their beliefs about the importance of innovating and diversifying teaching methods; and (iii) their plans to innovate and diversify in the future ${ }^{11}$. Knowing about their motivation is essential, but it is also necessary to investigate their knowledge and skills regarding innovative teaching-learning methods (capability), as well as if the environment supports methodological diversification and innovation (opportunity) ${ }^{11}$.

In summary, changing behavioral patterns can be a difficult task and evidence-based behavior change theories may represent a new paradigm for medical education when the goal involves overcoming behavioral problems.

\section{REFERENCES}

1. Costa NMSC, Cardoso CGLV, Costa DC. Conceptions about the good professor of medicine. Rev Bras Educ Med. 2012;36(4):499-505.

2. Costa NMSC. Medical teaching: why is it so difficult to change? Rev Bras Educ Med. 2007;31(1):21-30.

3. Rios LE. ABC of behaviour change theories: Critical review. Rev Bras Educ Med. 2017;41(2):356-8.

4. Rios LE. Behaviour change wheel: A guide for behaviour change interventions. Rev Bras Educ Med. 2016;40(1):144-7.

5. Michie S, Atkins L, West R. The behaviour change wheel: A guide to designing interventions. UK: Silverback Publishing, 2014.

6. Prochaska JO, DiClemente CC, Norcross JC. In search of how people change: Applications to addictive behaviours. Am Psychol. 1992;47(9):1102-114.

7. Hauer KE, Carney PA, Chang A, Satterfield J. Behaviour change counseling curricula for medical trainees: A systematic review. Acad Med. 2012;87(7):956-968.

8. Ajzen I. The theory of planned behaviour. Org Behav Hum Decis Process. 1991;50(2):179-211.

9. Archer R, Elder W, Hustedde C, Milam A, Joyce J. The theory of planned behaviour in medical education: a model for integrating professionalism training. Med Educ. 2008;42:771-7.

10. Brown J, West R. Theory of Addiction. 2nd ed. UK: WileyBlackwell, 2013.

11. Rios LE. Critical Review of the Book: Theory of Addiction. Rev Bras Educ Med. 2019;43(4):200-2.

\section{CONFLICTS OF INTEREST}

The author has no financial or nonfinancial competing interests related to this paper.

\section{ADDRESS FOR CORRESPONDENCE}

Leonardo Essado Rios. Instituto Federal de Educação, Ciência e Tecnologia de Goiás. Avenida Universitária, s/n. Vale das Goiabeiras. Inhumas, GO, Brasil. CEP: 75400-000.

E-mail: leonardo.rios@ifg.edu.br 